\title{
The challenge of rural life nostalgia: barriers in redevelopment of Malay Reserve Land (MRL) in Klang Valley
}

\author{
Noor-Rosly Hanif ${ }^{1 *}$, Wan Nor Azriyati ${ }^{1}$, Hamzah Abdul-Rahman², Chen Wang ${ }^{3}$ and Lincoln C Wood ${ }^{4}$
}

\begin{abstract}
The development of Malay reserve land is a nationwide issue which can be overcome through better understanding of the existing barriers. While many barriers have been examined, the challenges relating to land owner expectations and preferences has not been thoroughly examined. Using Kg Sungai Penchala in the capital city Kuala Lumpur as a case, this research used a structured interview survey of 258 respondents representing both owners and tenants. Statistical analysis demonstrates that majority of the land owners (individuals) rejected the idea to further develop the land. The land owners preferred to maintain the village status quo and they were satisfied with the current development level in the village. Only a minority of respondents agreed that the land should be developed and instead perceived that re-development of this Malay Reserve Land of Kg Sungai Penchala would be able to raise their quality of life. The restriction is much preferred by the land owners who preferred the current style of village living. Thus, immediate re-development of the area is not warranted and the preference of the land owners represents a strong barrier.
\end{abstract}

Keywords: Malay reserve land; Village life; Development restriction; Land owners; Rural life nostalgia

\section{Background}

In Malaysia, the Malay Reserve Land (MRL) refers to the land owned by the indigenous Malays. The Malay reserve land is stipulated under the Malay Reservation Enactment (Cap 142), which had been in force since 1913 and amended from time to time (Turnbull 1989; Sandhu 1964). Currently, most of Malay reserve land are either left idle or underutilized. Compared with its neighbors, Malay reserve land is considered as lagging behind its neighbors' economic development (Trezzini 2001). The land value for the non-Malay reserve is more than four times the value of Malay reserve land (Buang 1997). Consequently, issues related to the development of Malay reserve land are focused on the legislative barriers such as restrictions in land dealing, collateral, and multi-level ownerships (Yusof et al. 2010).

Since the Malay reserve lands are situated within the town boundaries, local planning authorities should have

\footnotetext{
* Correspondence: cipmgroup@gmail.com

${ }^{1}$ Centre for Studies of Urban and Regional Real Estate (SURE), Faculty of Built Environment, University of Malaya, 50603 Kuala Lumpur, Malaysia

Full list of author information is available at the end of the article
}

prepared development plans encompassing the area in which development policies have been outlined (Morshidi 2000). In addition, the development plan preparation report mentions that most of states in Peninsular Malaysia have had their structure plans and some local plans are deposited (Mitchell and Joseph 2010). However, a glance observation portrayed that the progress of physical development in Malay reserve lands is really slow (City Hall Kuala Lumpur 2000). The key questions are: what policies have been carried out by the responsible local authorities and agencies and what obstacles are faced during policy implementation. Besides the local authority's responsibilities, land owners are also required to devote more efforts in developing their land of at least equivalent to their neighbor's achievements. Financial aids have been arranged by the government. Therefore, the land owners' attitudes are questionable. The underlying factors that are influencing Malay reserve land owners against developing the land need to be further studied. This is the main motivator for the research; while existing barriers have been closely examined, it is clear that the attitudes and 
desires of the land owners has been neglected, even though this may represent a significant barrier.

The two research questions are: first, why has redevelopment in Malay reserve land located within vibrant urban areas fallen short of expectations; and, second, what are the major barriers to redevelopment. These questions led to the following research propositions: the development of Malay reserve land is a nation-wide issue which can be overcome through better understanding of the existing barriers. The recommendations of this study can be generalized and used to guide policy makers. The aims of this study are: to examine the current development policies and legislative provisions on MRL; to identify barriers for redeveloping MRL; and, to ascertain the main factors affecting land owners' behaviors and attitudes.

\section{Case description}

Malay Reserve Land (MRL)

The Malay Reserve Land (MRL) was created under the Malay Reservation Enactment of 1913 and the Land Enactment of 1987. The objective of the legislation was to ensure that the Malays would be able to own land, particularly in urban areas; a key provision is that MRL may not, either through sale or lease, be transferred to non-Malays (Meade 1976; D'Arcy and Keogh 1999). Thus, there would be perpetuation of the ownership of land under Malay settlement and cultivation, preserving the social, economic, and physical integrity of the Malay peoples (Means 1985). The land which is alienated to individuals under the term Malay reserve carries certain limitations and restrictions. The restriction is that the land owners are prohibited from disposing the land to non-Malays (Gomez 2003). Moreover, any dealing entered into with non-Malay affecting MRL is null and void. The amount of MRL in each state varies. For example, about a quarter of land in state of Melaka is MRL. The location and size for each block of MRL is vested to the state authority. Thus, the reserve land is scattered everywhere and tends to be located within town boundaries. In the capital city of Kuala Lumpur, there are six Malay Reservation Areas (Table 1).

Table 1 Six Malay reservation areas in Kuala Lumpur

\begin{tabular}{llll}
\hline Location & $\begin{array}{l}\text { Area (in } \\
\text { hectare) }\end{array}$ & Population & $\begin{array}{l}\text { Density (person } \\
\text { per hectare) }\end{array}$ \\
\hline Kg Bharu & 101.2 & 45,000 & 446 \\
Kg Datok Keramat & 87.58 & 25,000 & 286 \\
Segambut & 293.97 & 2,500 & 9 \\
Kg Sungai Penchala & 291.65 & 5,000 & 17 \\
Gombak & 320.61 & 20,000 & 62 \\
Selayang & 87.78 & 4,000 & 46 \\
Total & $1,182.61$ & 101,500 & \\
\hline
\end{tabular}

The Kuala Lumpur Structure Plan outlines that these MRL were originally conceived of and planned as traditional villages. The lots comprise individual dwelling units with associated lands sufficient to provide agricultural smallholdings. As the City has grown, the MRL that were originally located on the outskirts of the City have become surrounded by urban development; thus, many of the original buildings and settlements are no longer compatible with their surroundings. While Kampong Bharu, Kampong Datok Keramat, and Selayang are well laid out with internal roads, utilities, and community facilities, Gombak, Segambut, and Kampong Sungai Penchala have retained their original agricultural subdivisions and have consequently developed in a haphazard manner. In term of land usage, the MRLs are essentially residential, although almost $40 \%$ of Segambut and Kampong Sungai Penchala (mainly the hilly areas) are still undeveloped or used for agricultural purposes. Kampong Bharu and Kampong Datok Keramat are the most developed among the MRLs, followed by Gombak, Kampong Sungai Penchala, and Segambut (City Hall Kuala Lumpur 2000).

The legal restrictions imposed on property and the land ownership are the major factors that have reduced the financing potential and the marketability of these areas (Halik and Webley 2011). Other well-noted constraints include the lack of capacity of individual owners to develop their properties and the absence of clear implementation programs (Abdul-Aziz and Jahn-Kassim 2011). Currently, most Malay reserve land is either left idle or under-utilized. Physically, the Malay reserve land exhibits the agglomeration of irregularly arranged, nonpermanent structures for unplanned settlement, greened by agriculture activities and lack of basic infrastructures. Due to these attributes, Malay reserve land is considered to be far less valuable and generate less economic wealth than neighboring land. The land value for the nonMalay reserve is more than four times the value of Malay reserve land. Consequently, the issues related to the developing Malay reserve land are centered on the legislative obstacles such as restrictions in land dealing, collateral, and multi-level ownerships. Importantly, the issue of land shortage for housing development has been connected to the issue of Malay reserve land. Housing developers have claimed that the escalating urban land prices were partly related to less acreage of available freehold land compared to Malay reserve land. In other words, the housing developer's complaint is that the limited supply of land available for housing developments push prices upwards.

\section{Demand for land}

In the capital city of Kuala Lumpur, most of the Malay reserve lands are located surrounding town areas; thus, 
the high demand for land suitable for economic development leads to pressure for further development of Malay reserve land. The demand for land is associated with the urbanization rate, which has been high in the decades after Malaysia's independence from the British in 1957. The fast growing of towns in Peninsular Malaysia, particularly, in the period between 1960 and 1980 was partly due to the rural-urban migration seeking employment opportunities in urban centers coupled with natural increase in existing population. The significant growth was seen in new growing towns like Kuala Lumpur, Ipoh, Penang, and Johor Baharu. The rate of urbanization in 1970 was $28.8 \%$ and continued to increase yearly. By 1980, the rate of urbanization for Malaysia as a whole was $34.2 \%$ and $37.4 \%$ in 1985 that include Sabah and Sarawak in the fifth Malaysia plan. For Peninsular Malaysia alone the rate was $41.1 \%$ in 1985 and was increase with the average annual growth rate of $4 \%$ in the eight Malaysia plan. By 1990, the urban population for Malaysia was $50.7 \%$ out of the total population 18,379,655 people while for Peninsular Malaysia alone, the urban population was $54.3 \%$ of the total population $14,797,616$ people. The percentage of urban population was further increased in year 2000. There was $62 \%$ of population residing in urban areas for the whole country and $65.4 \%$ of $18,523,632$ people for the Peninsular. The share of urban population is seen to be greater in year 2020 of at least $75 \%$ while leaving another $25 \%$ residing in rural areas. This high share of urban population will be mostly distributed to the major conurbation areas in the Peninsular: Kuala Lumpur, Johor Bahru, Penang, and Kuantan (City Hall Kuala Lumpur 2000).

Besides other economic activities, the land for housing becomes the major issues because of its size, legislative provision, and characteristics that attached to its locality and cannot be found in other places (Abdul-Aziz et al. 2010). The land ownership, legal rights, and interested parties made development more difficult. Without any intervention from the government, the location of housing land will be at the outskirt of the central commercial districts because of lower land prices in the agriculture areas. In recent decades (1970s-2000s), vast tracts of Malaysian agricultural land was converted to become housing areas and support other urban economic activities; e.g., commercial and industrial sectors. This phenomenon would be reduced if all potential land in town areas is utilized to its maximum potentials (Abdul-Aziz et al. 2010).

Without too ambitious, the potential development of Malay reserve land can be seen on its present roles of which it has provided cheaper accommodations to many Malay families. Thus, the possibility to provide housing for rents is great since the demand for housing in many urban areas is seemed to be more acute in future years. The strong demand resulted from economic prosperity in the country comes from two types of home seekers; families seek for owner occupiers and also from families, couples or bachelors just to rents. The capital needed can be obtained from the financial institutions. This is because the financial institutions are now allowed to become 'artificial Malay' under the amended section 17 of CAP 142. By this way, commercial banks are able to accept Malay reserve lands as security for loans granted to their owners. For the other economic uses such as commercial and industry, more factors have to be analyzed that include locality, physical conditions, accessibility and economic performance. For this later prospect, the Conference on Malay Reserve Land, in November 1996 recommended that the state governments have to identify Malay reserve lands with high potential for future development (Buang 1997).

\section{Redevelopment}

Four key barriers to redevelopment are the financial barrier, the regulatory and institutional barriers, physical barriers and individuals' barriers (Kivell 1993; Schuman 1994; MRSCW 1997; Setterfield 1997). Financial barriers are where the cost of redevelopment of such properties (which are sometimes small and oddly shaped) is often higher than the cost of equivalently-sized properties outside the urban core. The lending practices also contribute to difficulties in obtaining funding for redevelopment. This financial barrier impacts the economics of decision-making that hinder redevelopment of particularly vacant and abandoned lands in the urban areas.

The second barrier is well-intended but flawed or poorly implemented regulations. Indeed, the government often devotes resources to encourage redevelopment but is often obstructed by its own laws and procedures. Community-centered, mixed-use redevelopment runs counter to many outdated zoning practices, practices that were designed for a different era and economy (Kivell 1993). Some redevelopment is similarly inhibited by burdensome requirements related to parking, drainage, landscaping, and infrastructure improvement requirements.

The establishment of rules and procedures as part of government bureaucracy can also act as barriers to redevelopment. In a similar tone, Schuman (1994) argued that the political lack of concern, ad hoc approaches to planning and development policy, and fragmentation of resources all act as procedural barriers to land redevelopment.

Physical characteristics of particular sites which create supply-side obstacles to redevelopment are the third key barrier to land redevelopment. The study by MRSCW (1997) 
argued that the small and awkwardly shaped plots can cause them to be less attractive targets for redevelopment. Similarly, environmental constraints such as steep slopes, streams, wetland areas are less common but still likely barriers faced by developers.

Finally, the fourth key barrier that hinders land redevelopment relates to personal or individual matters. Setterfield (1997) asserted that property owners for various reasons may create obstacles by unwillingness or an inability to allow redevelopment. Private owners may be reluctant to sell a property that will represent a financial loss or that could possibly increase in value in the future. In addition, there may be little incentive to sell because of the relatively low costs associated with carrying the property on as is.

\section{Redevelopment and inhabitants}

The redevelopment of urban villages has aroused academic attention since the mid-1990s. Most early scholarly works viewed urban villages as a social place, which was characterized by social networks based on migrants' places of origin (Liu and Liang 1997; Ma and Xiang 1998 and Zhang 2001). Recent research is more focused on examining the conflict between redevelopment and inhabitants. Hao et al. (2011) studied the development and redevelopment of urban villages in Shenzhen. In the absence of government help, urban villages have evolved in many cities to provide adequate and affordable housing for the rural migrants. However, the urban villages are rejected by policymakers and face aggressive demolition-redevelopment programs to replace them with formal urban neighborhoods. Hao et al. (2011) explores different dimensions of the development and redevelopment of urban villages in Shenzhen. By linking to the development practice of the city, the physical and socio-economic evolution of urban villages is found to be a result of the natural and logical response of the indigenous village population and the rural migrants in facing rapid economic development and social transition. Therefore, the demolitionredevelopment approach adopted by the government would be devastating not only for the rural migrants but also for the city's economy which is largely based on labor-intensive sectors. There is a complex relationship between cultural heritage and poverty. This relationship is particularly evident in the depletion of historical centers. In addition, when considered along with the impact of the intertwined forces of urbanization and modernization, it may result in the dangerous threatening of the cultural tracts, social structure and urban patterns of the poor living in historical centers. Razzu (2005) analyzed this complex relationship as it is manifested in Ga Mashie and its impacts on the poor indigenous population. Razzu (2005) also suggests some policy recommendations, in particular, the fact that urban redevelopment projects of dilapidated historical districts have to genuinely consider the delicate and peculiar environment in which they are based. The financial elements of the intervention, for instance, might have to be differentiated from the typical ones used in peripheral slum upgrading projects, opening new rooms for a substantial redistribution of wealth.

The increasing importance of social housing in order to deal with the emergency caused by the pressing demand, places in the foreground the need to redevelop the existing occupied land. Boeri et al. (2011) studied the redevelopment of the heritage of social housing in Italy by proposing the deepening of one case study, the Pilastro neighborhood, a significant example of social housing high density settlement, situated in the outskirts of Bologna in order to brought out the technical, functional and social factors, on which the level of quality of the settlement and the phenomena of social uneasiness depend. It also highlighted some factors that may pose a resistance to the measures of improvement. Since the 1980s, the redevelopment of squatter housing settlements has been a primary policy focus of the local and central authorities in Turkey. Their strategies have adopted two different models: one approach was not effective at generating redevelopment activity and produced low quality living environments, and the other approach resulted in dislocation and gentrification. Ozdemirli (2014) stresses three issues. First, redevelopment sites are areas where market forces failed; thus, they are perceived as high risk, low-demand, and low-return investments with high transaction costs. Second, institutions that lower transaction costs boost market forces and increase economic performance in property development. Third, local authorities remain active in urban redevelopment; despite having no direct tools for local economic development, they do have tools for urban development. Ozdemirli (2014) reformulates the basic transaction cost thesis and hypothesizes that local authorities can boost urban redevelopment by making changes to institutions or "the rules of the game" by increasing information flow, positive externalities and perceived returns and by decreasing transaction costs, negative externalities and risks, all of which motivate land owners and house-builders. Ozdemirli (2014) revealed that the local authorities can produce desirable results for less attractive neighborhoods with the help of marketing, institutional strategies and effective land use planning without leading to dislocation and gentrification. Ozdemirli (2014) suggests that institutional strategies are crucial for urban policies and future urban redevelopment activities.

The recent wave of rapid urbanization generated a specific form of urban development called a 'city village', 
characterized by the dual urban-rural structure and it initially accommodates the significant housing needs of rural migrants (Lin and Meulder 2012). Although the issues of city villages are specific and enormous, they evidently have a lot in common with issues of slum areas and dilapidated urban areas in developed and developing contexts, in which there already is a long experience with upgrading or urban renewal operations. Also in this specific context of upgrading and urban renewal, the strategic urban project approach is generally being advocated. It emphasizes vision development, the coproduction by stakeholders and the implementation of actions. Strategic urban projects are the cornerstone of this approach. Lin and Meulder (2012) sketches a conceptual framework for the strategic urban project approach for the sustainable redevelopment of city villages in Guangzhou. Adapting the method to deal with the multi-stakeholder environment and complex issues is indeed necessary in order to obtain a sustainable redevelopment. Planning the redevelopment of brownfields according to the principles of sustainable development is a significant challenge, particularly for rural brownfields that have little hope of attracting private investment. Sardinha et al. (2013) proposed a sustainability framework for rural brownfield redevelopment planning that incorporates the concerns and expectations of stakeholders in the process, aiming at the integration of various forms of place making. Sardinha et al. (2013) illustrates how the integration of different perspectives and forms of place making can lead to a locally adapted sustainable development overview that can support the redevelopment planning of a brownfield site in a rural setting.

\section{Research methodology}

The research commenced with secondary data collection, which led to a deeper understanding of the issues associated with the development of Malay reserve land, particularly on the policies and basic information provided to the area concerned. Based on these data and insights, the research team developed a series of suvey questions designed to generate data complementing existing approaches by examining the impact of rural life nostalgia and the strength of land owner opinions. After the survey questions were developed they were refined by checking them with other academic experts. Finally, primary data were collected through a structured interview survey among Malay reserve land owners and tenants in Kg. Sg. Penchala in Kuala Lumpur. The sample size for MRL owner is 142 and for MRL tenants it is 116 .

The population of $\mathrm{Kg}$. Sg. Penchala has continued to increase, which may be partly due to its location advantages. Being proximate to more expensive districts (e.g., Taman Tun Dr Ismail, Bardar Utama, Damansara Perdana and Desa Park City) this MRL seems to face uneconomic land uses and is left far behind though the

Table 2 Demography of MRL owners in Kg. Sg. Penchala

\begin{tabular}{|c|c|c|}
\hline Profiles & Frequency & $\%$ \\
\hline \multicolumn{3}{|l|}{ Age } \\
\hline $18-29$ & 12 & 8.5 \\
\hline $30-39$ & 27 & 19.0 \\
\hline $40-49$ & 44 & 31.0 \\
\hline $50-59$ & 31 & 21.8 \\
\hline 60 and above & 28 & 19.7 \\
\hline Overall & 142 & 100 \\
\hline Absolute Mean (age) & 47.1 & \\
\hline Absolute Median (age) & 48.0 & \\
\hline \multicolumn{3}{|l|}{ Educational Achievement Level } \\
\hline Primary or no formal education & 11 & 8.3 \\
\hline Lower secondary schooling & 17 & 12.9 \\
\hline Upper secondary schooling & 58 & 43.9 \\
\hline Diploma or polytechnic courses & 34 & 25.8 \\
\hline Basic degree or higher & 12 & 9.1 \\
\hline \multicolumn{3}{|l|}{ Marital Status } \\
\hline Married & 117 & 82.6 \\
\hline Single & 16 & 11.1 \\
\hline Widow/widowed & 9 & 6.3 \\
\hline \multicolumn{3}{|l|}{ Household Size } \\
\hline 2 or below & 8 & 5.7 \\
\hline $3-4$ & 54 & 38.3 \\
\hline $5-6$ & 62 & 44.0 \\
\hline More than 6 & 17 & 12.1 \\
\hline Absolute Mean & 4.88 & \\
\hline Absolute Median & 5.00 & \\
\hline \multicolumn{3}{|c|}{ Percentage of Families with Children still studying } \\
\hline Primary school & & 24.4 \\
\hline Secondary school & & 36.2 \\
\hline Matriculation studies & & 5.0 \\
\hline Local universities & & 29.4 \\
\hline Studying at overseas university & & 5.0 \\
\hline \multicolumn{3}{|l|}{ Total Household Income } \\
\hline RM1000 and below & 10 & 7.0 \\
\hline RM1001-2000 & 38 & 27.3 \\
\hline RM2001-3000 & 46 & 32.2 \\
\hline RM3001-4000 & 17 & 11.9 \\
\hline RM4001-5000 & 16 & 11.2 \\
\hline RM5001 and above & 15 & 10.5 \\
\hline Median = RM2001-3000 & & \\
\hline
\end{tabular}


Table 3 MRL owners' household income by occupation sector

\begin{tabular}{|c|c|c|c|c|c|c|}
\hline \multirow[t]{2}{*}{ Total household income } & \multicolumn{5}{|c|}{ Occupation sector } & \multirow[t]{2}{*}{ Total } \\
\hline & Government & Private sector & Self-employed & Retiree & Others & \\
\hline RM1000 and below & - & $2.2 \%$ & $7.9 \%$ & $15.4 \%$ & $8.3 \%$ & $9(6.5 \%)$ \\
\hline RM1001-2000 & $11.1 \%$ & $24.4 \%$ & $28.9 \%$ & $23.1 \%$ & $58.3 \%$ & $38(26.6 \%)$ \\
\hline RM2001-3000 & $44.4 \%$ & $42.2 \%$ & $21.1 \%$ & $34.6 \%$ & $8.3 \%$ & $46(32.4 \%)$ \\
\hline RM3001-4000 & $11.1 \%$ & $20.0 \%$ & $10.5 \%$ & $3.8 \%$ & $8.3 \%$ & $18(12.2 \%)$ \\
\hline RM4001-5000 & $11.1 \%$ & $4.4 \%$ & $23.7 \%$ & $7.7 \%$ & $8.3 \%$ & $16(11.5 \%)$ \\
\hline RM5001 and above & $22.2 \%$ & $6.7 \%$ & $7.9 \%$ & $15.4 \%$ & $8.3 \%$ & $15(10.8 \%)$ \\
\hline Total & 18 & 46 & 39 & 27 & 12 & $142(100 \%)$ \\
\hline
\end{tabular}

city faces a lack of land to meet various categories of urban economic activities. Based on City Hall of Kuala Lumpur's records, its population in 1980 survey was about 1,000 and then increased to 5,000 by 2000 . From a 'birds-eye view', the area is currently surrounded by high-class residential areas whereas its feature remains as the green island that can be identified along the LDP highway. Under the Kuala Lumpur Structure Plan study in 1980, some problems were identified and required special town planning considerations. Among others, the legislative provisions had engendered negative effects in the property market economy though the legislation will ensure the share of urban properties among Malays. Besides comprising larger areas of hilly land, the lacking of land owner positive attitudes and capabilities to develop their land as compatible as the non-MRL were obvious that required a form of a supporting agency.

Kampung Sungai Penchala is the most typical and representative Malay village in Kuala Lumpur, Malaysia with the postcode 60000 (Kuala Lumpur City Hall 2014). Despite the fact that the Government has gazetted Kampung Sungai Penchala as one of the Malay Reserve Lands in Kuala Lumpur, this village is being actively developed and is arguably the most rapidly developed areas in the past 10 years with many developments having taken place (Kuala Lumpur City Hall 2014). Kampung Sungai Penchala is located next to the established township of Taman Tun Dr Ismail and close to Mutiara Damansara (IKEA, Tesco and Ikano Power Centre) and Bandar Utama (1Utama shopping mall) that were once part of a large oil palm plantation. In

Table 4 Status of ownership of property in $\mathrm{Kg}$. Sg. Penchala

\begin{tabular}{lll}
\hline Ownership & Frequency & \% \\
\hline Individual & 91 & 64.5 \\
Family ownership & 45 & 31.9 \\
Others & 6 & 3.5 \\
& 142 & 100.0 \\
\hline
\end{tabular}

1998, the Damansara-Puchong Expressway (LDP) was opened, connecting Kampung Sungai Penchala to Bandar Sri Damansara, Sungai Buloh, Kepong and Gombak through the MRR2 to the north and to Damansara Utama, Damansara Jaya, SS2 and Kelana Jaya to the south. In 2004, the SPRINT Highway was opened, connecting Kampung Sungai Penchala to Kuala Lumpur and Mont Kiara/Sri Hartamas via the Penchala Tunnel. It is also 3 minutes' drive to the Damansara-Ulu Klang Expressway (DUKE) which leads to Gombak, Ampang and Ulu Kelang. Five minutes' away is the New Klang Valley Expressway (NKVE) with connections to Ipoh to the north and Shah Alam, Bukit Raja and Klang to the west as well as Cyberjaya, Putrajaya, KLIA and Nilai to the south. Kampung Sungai Penchala now has two mosques, Masjid Al-Hidayah, as well as Masjid Jamek Tengku Abdul Aziz Shah. Kampung Sungai Penchala currently has a population made up of various ethnicities from a number of regions and states from Indonesia, such as Kerinchi, Boyan or Bawean, Java, and Minangkabau who have long lived in the village. Kampung Sungai Penchala can be further broken down into a number of smaller villages, namely: a) Kampung Penchala Indah, b) Kampung Palimbayan, and c) Kampung Palimbayan Indah (Kuala Lumpur City Hall 2014). These factors are similar to other Malay reserve lands; therefore, we conducted our study in this region as Kampung Sungai Penchala appears to be a relatively representative case.

\section{Kg. Sg. Penchala Demographics}

The highest proportion of the representatives of the MRL owners captured in this study is the group aged 40 to 49 years (31\%); those aged 50 to 59 years constitute $22 \%$, and those aged 60 years above comprised $20 \%$ of the sample. The greater representation of those in older categories concurs with the mean value at 47 years and the median age at 48 years. This can be taken as good as the older generation interviewed may have stayed at the village for a long time and would have had substantial experience with the issues raised by this study. 
Table 5 Whether MRL ought be developed and underlying reasons for this

\begin{tabular}{lll}
\hline Reasons & \multicolumn{2}{l}{ Land should be developed? } \\
\cline { 2 - 3 } & Yes (\%) & No (\%) \\
\hline Build houses to rent & 14.3 & \\
Bring development & 21.4 & \\
Depends on government policy & 7.1 & \\
For commercial value & 35.7 & \\
For agriculture & 7.1 & 67.3 \\
Raise living standards & 14.3 & 23.6 \\
Remain as it is & & 5.5 \\
Enough development & & 1.8 \\
No need to develop & & 1.8 \\
Inherited land & & \\
Lose Malay rights & & \\
\hline
\end{tabular}

Nearly 70\% of the MRL owners have a high level of education of at least upper-secondary level, a polytechnic certificate, or a diploma. In addition, another $9 \%$ of the respondents had a tertiary educational qualification. Only about 20\% MRL owners have only primary schooling or lower education. In other words, the MRL owners are quite varied in terms of their educational attainment. Around 83\% MRL owners were married and the raw household size is 4.88 persons (the median is 5 persons). About 44\% MRL owners have 5 or 6 children. Upon the education level of children, $24.4 \%$ families have their children admitted by primary schools, and $36.2 \%$ enrolled into secondary schools. Furthermore, $29.4 \%$ are studying at local universities. Table 2 summarizes the profiles of the MRL owners involved in this study.

Table 3 demonstrates that a larger proportion of those MRL owners who are self-employed (24\%) earn between RM4000 and RM5000 per month, which is relatively large compared with those in other sectors. In addition, a larger proportion of those in the government sector and among retirees earn more than RM5000 per month. This may suggest that the village is sought after, partly, by government employees who would like to retire in a village environment, treating it as a retirement home.

Besides the 142 MRL owners, a total of 116 MRL tenants were interviewed immaterial of whether they are locals or foreigners occupying the housing unit. Out of the $116 \mathrm{MRL}$ tenants, 94 (81\%) of them were Malaysians and the remaining 22 (19\%) were foreigners. A large majority of the foreign tenants are Indonesians (>80\%). The highest proportion (40\%) of the MRL tenants falls into the 30-39 age category and the average age of the Malaysian tenants is 37.6 years old. Most tenants (84\%) are married. Sixty percent of the respondents are employed in the private sectors while 19\% are engaged with the public service. Those who are self-employed are only $12 \%$. Most of the tenants $(84 \%)$ have 3 to 6 members in the family. The average household size is 4.63 persons and the average number of children is 1.45 persons, implying that a significant number of these houses have more adults than children. The average number of children in primary schools per household is 0.9 , while that for secondary schools is 0.5 and for tertiary education is 0.1 only.

\section{Discussion and evaluation \\ Research findings \\ Study among MRL owners in Kg. Sg. Penchala}

In respect of the status of ownership, a large number of properties $(64.5 \%)$ are individually-owned and a further one-third is jointly-owned with family members of original family (see Table 4).

Among these MRL owners, only 21\% have ever tried to develop their land. Further, of this cohort, they tried only in building for rent and in renovating existing premises. The other $79 \%$ who have never

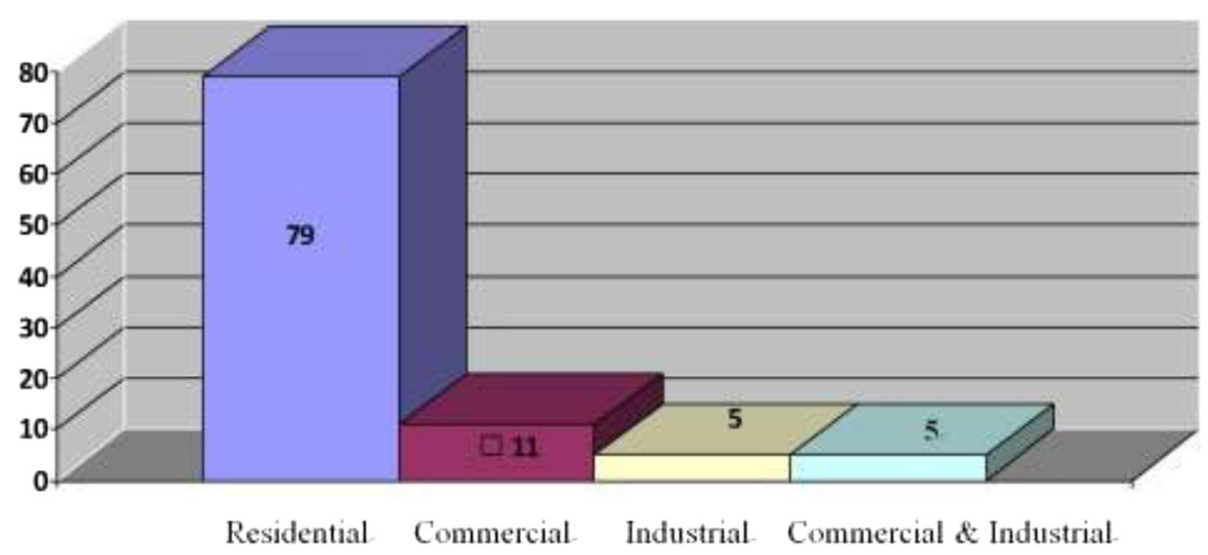

Figure 1 Type of development preferred by MRL owners. 


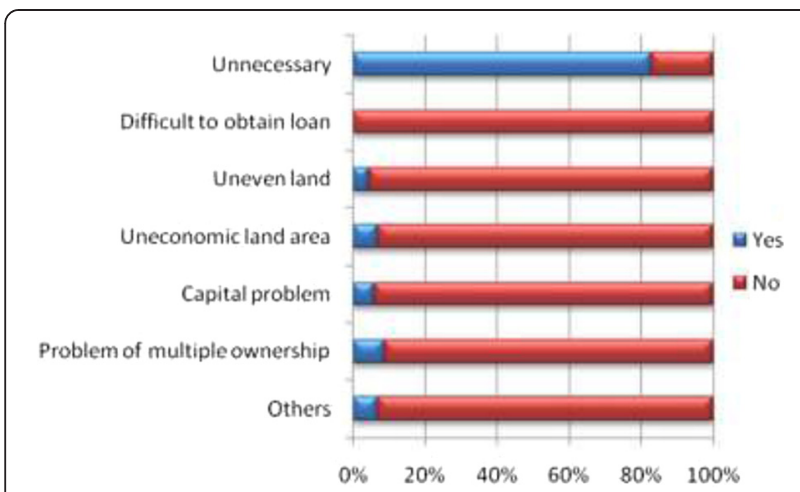

Figure 2 Reasons for MRL owners' lack of interest to develop MRL in future.

tried to develop their land are already satisfied with the current level of development. Similar observations are recorded in Table 5 regarding whether the land should be developed. Among those who rejected the idea to further develop the land, $80 \%$ preferred to maintain the village status quo and they were satisfied with the level of development in the village. On the other hand, only about 20\% agreed that the land should be developed, and the development should be based on economic returns (e.g., rental, carrying out small businesses, and support development of the village) that would be able to raise the quality of life for all inhabitants.

MRL owners presented their plans to develop the land in the future. Figure 1 illustrates the type of development preferred by them. Apart from about 21\% who would like to have commercial and industrial establishments at the site of their village, majority (79\%) preferred more residential units.

Figure 2 provides the responses of those MRL owners who did not plan to develop their land in future. Consistent with the strong intention to maintain their land, over $80 \%$ responded that was unnecessary to develop the land. None complained that they could not obtain a loan to finance their development plan. Other reasons raised included the uneven land, uneconomic land area, problems in raising funds despite availability of bank loans, and multiple ownership of the land.

\section{Study among MRL tenants in Kg. Sg. Penchala}

The MRL tenant households earn a median income between RM1000 and RM1500 per month. Half of the MRL tenants (48\%) earn between RM2000 and 3000 per month and one-fifth of the tenants (22\%) earn a total household income above RM3000 per month. Only $12 \%$ of the MRL tenants have an income below RM1500 per month. Table 6 indicates that a greater proportion of MRL tenants who earn more than RM3000 per month are employed in the public sector.

The reasons for MRL tenants electing to rent a house in this village are studied. Table 7 demonstrates that cheaper rent appears to be the most important reason (38\%) for MRL tenants to rent the current premise in Kg. Sg. Penchala. The second important reason is the close proximity to their work place (35\%). In other words, almost three quarters (73\%) of the respondents regard affordability of rental and proximity to work place as the two most important reasons to reside in this village. These reasons are consistent with that of the MRL owners' choice of place, which is related to their occupation and relatively cheaper rental compared with other areas.

Similarly to the MRL owners, most MRL tenants (95 persons or $82 \%$ ) responded negatively to the question about whether the village they currently reside in should be developed. On the other hand, 21 MRL tenants showed slight favor in developing the village, among which 14 tenants provided their reasons. The reasons provided by these 14 MRL tenants include "Malays must move forward to compete to participate with the rest in the development of the country" and "the current village needs more public facilities". The reasons for the rest $95 \mathrm{MRL}$ tenants not supporting development of Kg Sg

Table 6 Household income of MRL tenants by occupation sector

\begin{tabular}{|c|c|c|c|c|}
\hline \multirow[t]{2}{*}{ Total household income } & \multicolumn{4}{|l|}{ Occupation sector } \\
\hline & Government sector & Private sector & Self-employed & Others \\
\hline RM1000 and below & $11.8 \%$ & $3.6 \%$ & - & - \\
\hline RM1001-1500 & $5.9 \%$ & $3.6 \%$ & $10 \%$ & $20 \%$ \\
\hline RM1501-2000 & $11.8 \%$ & $19.6 \%$ & $10 \%$ & $20 \%$ \\
\hline RM2001-2500 & $5.9 \%$ & $25.0 \%$ & $50 \%$ & $60 \%$ \\
\hline RM2501-3000 & $23.5 \%$ & $26.8 \%$ & $20 \%$ & - \\
\hline RM3001-4000 & $17.6 \%$ & $10.7 \%$ & - & - \\
\hline RM4001 and above & $23.5 \%$ & $10.7 \%$ & $10 \%$ & - \\
\hline Total (number) & $100 \%$ & $100 \%$ & $100 \%$ & $100 \%$ \\
\hline
\end{tabular}


Table 7 Rank of Reasons for Renting at Kg. Sg. Penchala

\begin{tabular}{lll}
\hline Rank of importance & Frequency & $\%$ \\
\hline Cheaper rent & 33 & 38.0 \\
Near work place & 30 & 34.5 \\
Comfortable with own people around & 10 & 11.5 \\
Near family & 6 & 6.9 \\
Near school & 4 & 4.6 \\
Good public facilities & 2 & 2.3 \\
Family inheritance & 1 & 1.1 \\
Near mosque & 1 & 1.1 \\
\hline
\end{tabular}

Note: Multiple responses obtained.

Penchala are presented in Figure 3. The top two reasons are "comfortable village style" (44\%) and "to maintain village environment" (28\%). Other reasons are "it's Malay reserve land" (7\%), "other race will come in" (2\%), "will be polluted" (2\%), "most land are occupied" (2\%), "cheaper this way" (3\%), "rare village in urban area" (6\%), "social problems will rise" (4\%), "near developed area" (1\%), and "maintain good land value" (1\%).

\section{Discussions}

The development of Malay reserve land (MRL) has been found to be slow; its development is insignificant relative to the overall city physical landscape. By looking at Sg. Penchala in Kuala Lumpur, though MRL is a part of the federal territory and has been given development incentives, its location advantages have not been exploited for better economic uses. It is foreseen that the future needs for housing and other economic uses in the city will further pressure these areas to be developed. The improper planning and much leeway of development control, as of the past, will likely dampen the Urban-Malay fortune. However, the development in these areas to meet the development plan objectives depends on landowners' attitudes and the availability of financial aid. Since the property market may have some influence on the potential development, it is argued here that barriers for the development should be first ascertained for which remedial actions can be formulated.

These data indicate that there is a strong 'rural life nostalgia' amongst the owners in Malay reserve land. This is exhibited by the strongly stated preference for the village style of living in the current environment. Without addressing this preference, policymakers will struggle to enact effective changes in the redevelopment of this land.

\section{Conclusions}

This study showed that the barriers in development process faced by the Malay Reserve Land of $\mathrm{Kg}$. Sg. Penchala cannot be resolved by merely proposing specific developments or attempting to resolve specific issues. These development barriers relate to a range of legal, physical, and financial issues and require effective coordination and promotion and this can only be undertaken by a dedicated body. Most importantly, policymakers must address the restriction originating from the land owners themselves, who perceive that the current environment of village style of living is much preferred. Thus, immediate re-development of the area is not warranted. Further studies should be conducted to seek possible solutions in developing these MRL while giving considerations to the MRL owners' favored life style.

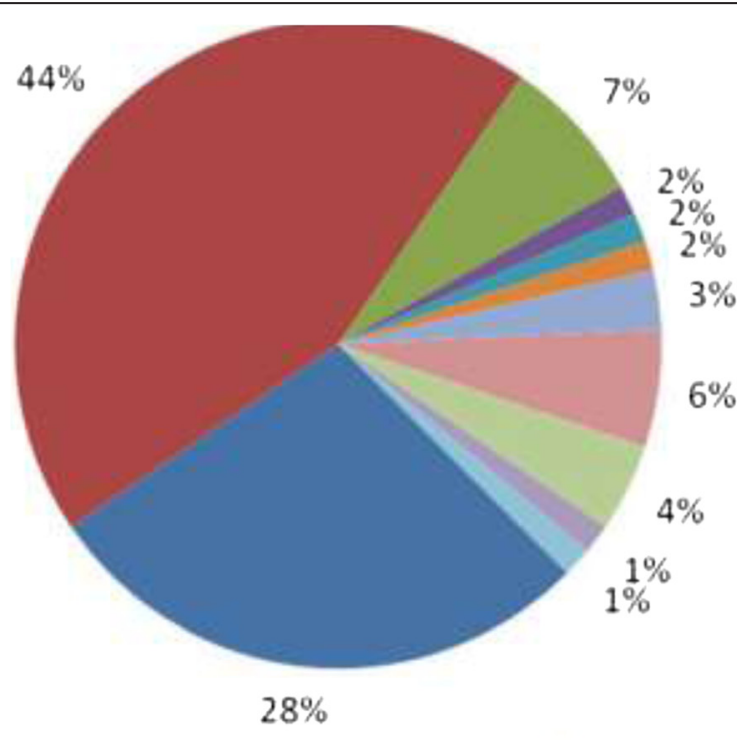

maintain village environment

- Comfortable village style

It is Malay Reserve Land

- Other races will come in

Will be polluted

Most land are occupied

\# Cheaper this way

* Rare village in urban area

In Social problems will rise

Near developed area

Maintain good land value

Figure 3 MRL tenants' reasons for not supporting development of Kg. Sg. Penchala. 


\section{Competing interests}

The authors declare that they have no competing interests.

\section{Authors' contributions}

$\mathrm{NRH}$ developed the research concept and scope, and lead the case study. WNA conducted the case study as a co-leader. HAR jointed the data analysis and writing. CW is in charge of data analysis, interpretation and visualization. LCW is in charge of writing and proofreading. All authors read and approved the final manuscript.

\section{Author details}

${ }^{1}$ Centre for Studies of Urban and Regional Real Estate (SURE), Faculty of Built Environment, University of Malaya, 50603 Kuala Lumpur, Malaysia. ${ }^{2}$ ViceCancellor's Office, International University of Malaya-Wales (IUMW), 50408 Kuala Lumpur, Malaysia. ${ }^{3}$ Centre for Construction Innovation and Project Management (CIPM), Faculty of Built Environment, University of Malaya, 50603 Kuala Lumpur, Malaysia. ${ }^{4}$ Faculty of Business and Law, Auckland University of Technology, Private Bag 92006, Auckland 1142, New Zealand.

Received: 16 September 2014 Accepted: 11 December 2014

Published online: 10 February 2015

\section{References}

Abdul-Aziz AR, Jahn-Kassim PS. Objectives, success and failure factors of housing public-private partnerships in Malaysia. Habitat Int. 2011;35(1):150-7.

Abdul-Aziz AR, Jaafara M, Nuruddin AR, Lai SW. Using institutional theory and resource-based perspective to aid transformation of housing-related public enterprises in Malaysia. Habitat Int. 2010;34(2):196-203.

Boeri A, Antonini E, Longo D, Roversi R. The redevelopment of the heritage of social housing in Italy: survey and assessment instruments: the case study of Pilastro neighborhood in Bologna. Procedia Engineering. 2011;21:997-1005.

Buang S. New dimensions community development: legal papers. Kuala Lumpur: Language and literature Hall Publisher; 1997.

City Hall Kuala Lumpur. Structure plan Kuala Lumpur 2020. Kuala Lumpur: Percetakan Nasional Negara; 2000.

D’Arcy E, Keogh G. Kuala Lumpur. In: Berry J, McGreal S, editors. Cities in the pacific rim: planning systems and property markets. London: E \& FN Spon; 1999. p. 157-67.

Gomez ET. Capital development in Malaysia. In: Proceedings of CEDER Conference, Kuala Lumpur, Malaysia. 2003. p. 71-140.

Halik M, Webley P. Adolescents' understanding of poverty and the poor in rural Malaysia. J Econ Psychol. 2011;32(2):231-9.

Hao P, Sliuzas R, Geertman S. The development and redevelopment of urban villages in Shenzhen. Habitat Int. 2011;35(2):214-24.

Kivell P. Land and the city: patterns and processes of urban change. London: Routledge; 1993.

Kuala Lumpur City Hall. 2014 http://www.dbkl.gov.my/index.php?lang=en

Lin Y, Meulder BD. A conceptual framework for the strategic urban project approach for the sustainable redevelopment of 'villages in the city' in Guangzhou. Habitat Int. 2012;36(3):380-7.

Liu XL, Liang W. Zhejiangcun: social and spatial implications of informal urbanization on the periphery of Beijing. Cities. 1997;14(2):95-108.

Ma LJC, Xiang B. Native place, migration and the emergence of peasant enclaves in Beijing. The China Quarterly. 1998;155:546-81.

Meade M. Land development and human health in West Malaysia. Ann Assoc Am Geogr. 1976;66(3):428-39.

Means GP. The orang asli: aboriginal policies in Malaysia. Pac Aff. 1985;58(4):637-52.

Mitchell H, Joseph S. Changes in Malaysia: capital controls, prime ministers and political connections. Pac Basin Financ J. 2010;18(5):460-76.

Morshidi S. Globalising Kuala Lumpur and the strategic role of the producer services sector. Urban Stud. 2000;12:2217-40.

MRSCW. Infill development: strategies for shaping livable neighborhoods. 1997. Report No. 38, Municipal Research \& Services Centre of Washington.

Ozdemirli YK. Alternative strategies for urban redevelopment: a case study in a squatter housing neighborhood of Ankara. Cities. 2014;38:37-46.

Razzu G. Urban redevelopment, cultural heritage, poverty and redistribution: the case of Old Accra and Adawso House. Habitat Int. 2005;29(3):399-419.

Sandhu KL. Emergency resettlement in Malaya. J Trop Geogr. 1964;18:157-83.

Sardinha ID, Craveiro D, Milheiras S. A sustainability framework for redevelopment of rural brownfields: stakeholder participation at São Domingos Mine, Portugal. J Clean Prod. 2013;57:200-8.
Schuman DR. Revitalizing Low-income neighbourhoods: recommendations from ULI Advisory Servies Panels. Washington DC: Urban Land Institute; 1994.

Setterfield M. Abandoned buildings: models for legislative \& enforcement reform, research project 23. Hartford: Trinity Center for Neighborhoods; 1997.

Trezzini B. Embedded state autonomy and legitimacy: piecing together the Malaysian development puzzle. Economic Society. 2001;30(3):324-53.

Turnbull CM. A history of Malaysia, Singapore and Brunei. Sydney, Australia: Allen \& Unwin; 1989

Yusof NA, Shafiei MWM, Yahya S, Ridzuan M. Strategies to implement the "build then sell" housing delivery system in Malaysia. Habitat Int. 2010;34(1):53-8.

Zhang L. Strangers in the city: reconfigurations of space, power, and social networks within China's floating population. Stanford: Stanford University Press; 2001.

\section{Submit your manuscript to a SpringerOpen ${ }^{\odot}$ journal and benefit from:}

- Convenient online submission

- Rigorous peer review

- Immediate publication on acceptance

- Open access: articles freely available online

- High visibility within the field

- Retaining the copyright to your article

Submit your next manuscript at $>$ springeropen.com 